\title{
Regulation of Insulin-Like Growth Factor-II Expression and Its Role in Autocrine Growth of Human Neuroblastoma Cells
}

\author{
D.M. MARTIN and E.L. FELDMAN* \\ Department of Neurology and the Neuroscience Program, University of Michigan, \\ Ann Arbor, Michigan 48104
}

\begin{abstract}
Insulin-like growth factor-II (IGF-II) is highly expressed in fetal tissues and may act as an autocrine growth factor during early embryogenesis. The $\mathrm{SH}-\mathrm{SY} 5 \mathrm{Y}$ human neuroblastoma cell line also expresses IGF-II and its receptors and responds to exogenous IGF-II with increased DNA synthesis, cell division, and neuritic outgrowth. For this study, we tested the hypothesis that IGF-II mediates autocrine growth of SH-SY5Y cells in serum-free media. SH-SY5Y cells plated at high densities proliferated in serum-free media, whereas sparsely plated cells did not. IGF-II mRNA levels increased within 24 hours of serum deprivation and were associated with increased immunoreactive IGF-II protein. Exogenous addition of IGF-II increased ${ }^{3} \mathrm{H}-\mathrm{TdR}$ incorporation and cell number in a dose- and timedependent fashion. By nuclear labelling experiments using 5-Bromo-2' deoxyuridine (BrdU), we detected a twofold higher percentage of $S$ phase nuclei after a 24-hour incubation in IGF-II. Treatment of SH-SY5Y cells with anti-IGF-II antibodies in serum-free media inhibited cell proliferation, and this inhibition was partially overcome by the addition of increasing concentrations of IGF-II. Collectively, our results indicate that IGF-II mediates an autocrine growth mechanism in SH-SY 5 Y cells that is associated with increased IGF-II expression.

(c) 1993 Wilcy-Liss, inc.
\end{abstract}

Insulin-like growth factor II (IGF-II) belongs to a family of proteins that exerts insulin-like metabolic and growth-promoting effects on many tissues (Rotwein, 1991). In developing fetal neuroblasts, IGF-II stimulates neuritic outgrowth, DNA synthesis, and cell proliferation (Bothwell, 1982; Recio-Pinto et al., 1986; DiCicco-Bloom and Black, 1988). IGF-II effects on cell growth have been shown to be mediated via interaction with specific transmembrane proteins, the type I and type II IGF receptors (Roth, 1988). The type I IGF receptor is structurally homologous to the insulin receptor, with four $\left(\alpha_{2}, \beta_{2}\right)$ transmembrane-spanning subunits and an intracellular tyrosine kinase domain (Morgan et al., 1986). In contrast to the type I IGF receptor, the type II IGF receptor is identical to the mannose-6 phosphate (Man-6 P) receptor and is responsible for targetting intracellular lysosomal enzymes (Morgan et al., 1987). IGF-II, acting through the type I or type II IGF receptor, has been shown to promote autocrine growth of other neuroblastoma cells (E1Badry et al., 1989) and several nonneuronal tissues and cell types, including mouse embryos (Rappolee et al., 1992) and muscle cells (Florini et al., 1991).

The human IGF-II and IGF receptor genes are expressed in cells of developing and adult mammalian nervous systems (Helper and Lund, 1990; Sara and Hall, 1990; McKelvie et al., 1992), and are also present in the SH-SY5Y human neuroblastoma cell line (Martin et al., 1992). SH-SY5Y cells, thought to have arisen from the neural crest (Biedler et al., 1978), are often used as a model for neuronal development (Påhlman et al., 1990). IGF-II stimulates DNA synthesis and proliferation (Mattsson et al., 1986, 1990; Feldman and Randolph, 1991) of SH-SY5Y cells and also enhances neurite formation over a 7-day period (Recio-Pinto and Ishii, 1988; Feldman and Randolph, 1991). Endogenous production of IGF-II and IGF receptors in SH-SY5Y cells, combined with the responsiveness of these cells to exogenously added IGF-II, has led to the hypothesis that SH-SY5Y cells may use IGF-II as an autocrine growth or survival factor (Påhlman et al., 1990).

In this study, we assayed the effects of endogenously produced and exogenously added IGF-II on the SHSY5Y cell cycle. In serum-free media, SH-SY5Y cells exhibited density dependent growth, which was specifically inhibited by anti-IGF-II antibodies. IGF-II expression rapidly increased in serum-free media, at both the mRNA and protein levels. IGF-II stimulated SH-SY5Y cell DNA synthesis and entry into $\mathrm{S}$ phase but did not change the distribution of cells within the cell cycle. Our results are discussed in the context of autocrine IGF-II mediated growth and effects on cell cycle.

Received October 12, 1992; accepted December 17, 1992.

*To whom reprint requests/correspondence should be addressed. 


\section{MATERIALS AND METHODS}

Tissue culture flasks were purchased from Corning Glass Works (Corning, NY) and Costar (Cambridge, MA). Calf serum (CS) and Dulbecco's Modified Eagles Medium (DMEM) were from Gibco BRL (Gaithersburg, MD). Restriction enzymes were obtained from Boehringer Mannheim (Indianapolis, IN) and Gibco BRL. ${ }^{32} \mathrm{P}$-dCTP was purchased from NEN Dupont (Boston, MA). Recombinant human IGF-II (from Bachem, Torrance, $\mathrm{CA}$, or Bisource International, Westlake, CA) was stored in $10 \mathrm{mM}$ acetic acid at $-70^{\circ} \mathrm{C}$. 5-Bromo- $2^{\prime}$ deoxyuridine (BrdU) was purchased from Sigma Chemical Co. (St. Louis, MO) and stored in $10 \mathrm{mM}$ aliquots in water at $-20^{\circ} \mathrm{C}$. Murine monoclonal antirat IGF-II antibody was purchased from Upstate Biotechnology (Lake Placid, NY). Monoclonal MOPC-21 antibody was purchased from Organon Teknika (Durham, NC). Dimethyl formamide was from Fluka (Ronkonkoma, NY). Unless indicated, all other chemicals were purchased from Sigma.

\section{Cell culture}

SH-SY5Y human neuroblastoma cells (Biedler et al., 1978) were kindly provided by Dr. Stephen Fisher (University of Michigan Medical Center). Cells were maintained in DMEM and $10 \% \mathrm{CS}$ at $37^{\circ} \mathrm{C}$ in a humidified atmosphere with $10 \% \mathrm{CO}_{2}$ and routinely subcultured after removal with trypsin-EDTA.

\section{DNA synthesis and cell proliferation assays}

SH-SY5Y cells were plated in 6-wells $\left(3-12 \times 10^{5}\right.$ cells per $3.5 \mathrm{~mm}$ well) in DMEM $+10 \% \mathrm{CS}$ and allowed to grow for 2 days. Medium was then removed, cells were rinsed thoroughly with DMEM, and DMEM \pm $10 \% \mathrm{CS}$ was added. ${ }^{3} \mathrm{H}$-TdR incorporation and cell number were assayed in parallel wells either immediately (no media change) or at various times after this change of media. For ${ }^{3} \mathrm{H}-\mathrm{TdR}$ incorporation studies, ${ }^{3} \mathrm{H}-\mathrm{TdR}$ ([methyl- $\left.{ }^{3} \mathrm{H}\right]$ thymidine, $6 \mu \mathrm{Ci}, 6,700 \mathrm{Ci} / \mathrm{mol}, \mathrm{NEN} \mathrm{Du}$ Pont, Boston, MA) was added to each well for a 2 -h incubation at $37^{\circ} \mathrm{C}$. Cells were washed with PBS and $5 \% \mathrm{TCA}$, and $1 \mathrm{ml}$ of $0.1 \% \mathrm{SDS} / 0.1 \mathrm{~N} \mathrm{NaOH}$ was added for a 1-h incubation at $37^{\circ} \mathrm{C}$. An aliquot of the TCAinsoluble radioactivity was measured by liquid scintillation counting on a 2000CA scintillation counter (Packard, Downers Grove, IL). Cell number was determined in parallel wells by trypan blue dye exclusion with a hemacytometer as previously described (Feldman and Randolph, 1991). Cell proliferation was measured by a colorimetric assay that detects reduction of the tetrazolium salt MTT (Hansen et al., 1989). For these experiments, cells were plated $\left(3-12 \times 10^{4}\right.$ cells/ $\left.\mathrm{cm}^{2}\right)$ in $100 \mu \mathrm{l}$ media in 96-well plates. MTT $(3(4,5-$ dimethylthiazol-2-yl)2,5-diphenyltetrazolium bromide) was added to a final concentration of $1 \mathrm{mg} / \mathrm{ml}$ for a 2 -h incubation at $37^{\circ} \mathrm{C}$. Lysis buffer $(0.1 \mathrm{ml}$ of $50 \%$ dimethyl formamide, $20 \% \mathrm{w} / \mathrm{v}$ SDS, pH 4.7) was added and cells were incubated at $37^{\circ} \mathrm{C}$ overnight. Optical densities (OD) of individual wells were determined using a Dynatech MR700 ELISA reader (Dynatech Laboratories, Cleveland Heights, $\mathrm{OH}$ ) with lysis buffer as the blank. After correction for nonspecific absorbance (630 $\mathrm{nm})$, there was a linear relationship between cell den- sity and $570 \mathrm{~nm}$ OD within the range of densities used for this study.

\section{Analysis of DNA content}

SH-SY5Y cells were plated $\left(3 \times 10^{4}\right.$ cells $/ \mathrm{cm}^{2}$ in T75 or T150 flasks) in DMEM $+10 \%$ CS and allowed to grow for 2 days. Medium was removed, cells were rinsed with DMEM, and fresh DMEM $\pm 10 \%$ CS or \pm 3 or $10 \mathrm{nM}$ IGF-II was added. After 0,1 , or 3 days, cells were removed by trypsinization and washed twice in HBSS (Hank's Balanced Salt Solution, Gibco BRL, Grand Island, NY). Cells were then fixed in ice-cold $70 \%$ ethanol and stored at $4^{\circ} \mathrm{C}$. SH-SY5Y cells were washed twice in HBSS, stained overnight at $4^{\circ} \mathrm{C}$ in 18 $\mu \mathrm{g} / \mathrm{ml}$ propidium iodide, $40 \mu \mathrm{g} / \mathrm{ml}$ RNase A in HBSS, and passed 2-5 times through an 18-gauge syringe needle to reduce clumping. Flow cytometry data were collected with the Epics Elite (Coulter Cytometry, Hialeah, FL). Cell cycle analysis was performed using the Multicycle software program (Phoenix Flow Systems, San Diego, CA).

\section{BrdU cell proliferation assay}

For BrdU labelling, SH-SY5Y cells were plated $\left(5 \times 10^{4}\right.$ cells per $3.5 \mathrm{~cm}$ well) on glass coverslips and maintained in $10 \%$ CS for 2 days. Cells were then rinsed with DMEM, and fresh DMEM \pm IGF-II $(10 \mathrm{nM})$ was added. After 1,3 , or 5 days, with a media change on day 4 , BrdU was added to a final concentration of $1 \mu \mathrm{M}$ for a 3-h incubation at $37^{\circ} \mathrm{C}$. Cells were then rinsed in pre-warmed $\left(37^{\circ} \mathrm{C}\right)$ HBSS and fixed for $5 \mathrm{~min}$ at room temperature in $4 \%$ paraformaldehyde in $0.1 \mathrm{M}$ phosphate buffer, $\mathrm{pH} 7.4$. Cells were stored at $4^{\circ} \mathrm{C}$ in $1 \%$ paraformaldehyde. BrdU incorporation into nuclei was detected immunocytochemically, using an antibody specific for BrdU. For BrdU labelling reaction, nuclei were denatured by washing for $30 \mathrm{~min}$ in $2 \mathrm{~N} \mathrm{HCl} / 0.15 \%$ Triton-x 100. To prevent nonspecific antibody binding, cells were incubated for $30 \mathrm{~min}$ in $2 \%$ normal rabbit serum (Vector Laboratories, Burlingame, CA). Cells were incubated with a monoclonal rat anti-BrdU antibody (1:2500 in PBS, Accurate Chemical and Scientific, Westbury, NY) for $90 \mathrm{~min}$ in a moist chamber. A Vectastain rat $A B C$ Immunoperoxidase kit (Vector Laboratories) was used for secondary antibody labelling, with hydrogen peroxide, diaminobenzidine tetrahydrochloride (DAB), and 5\% nickel chloride. Coverslips were wetmounted in a solution containing $50 \%$

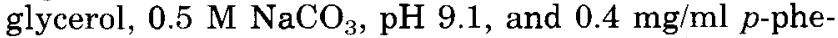
nylenediamine as an antibleaching agent. Cells were visualized and the percentage of total nuclei labelled with BrdU determined by image analysis microscopy.

\section{Northern analysis and cDNA probes}

Northern analysis was performed essentially as previously reported (Martin et al., 1992). SH-SY5Y cells $\left(2.5 \times 10^{4} \mathrm{cells} / \mathrm{cm}^{2}\right.$ in T150 flasks) were plated in DMEM/10\% CS and allowed to grow for 2 days. The medium was then removed, cells were rinsed twice in DMEM, and DMEM $\pm 10 \%$ CS was added. RNA was isolated immediately (no media change) or at various times after this change of media, using guanidine thiocyanate extraction (Chomczynski and Sacchi, 1987). Total RNA $(20 \mu \mathrm{g})$ was separated by size in for- 
maldehyde-agarose gels and transferred to nylon $\mathrm{Ny}$ tran membranes (Schleicher and Schuell, Keene, NH). Membranes were successively hybridized with ${ }^{32}$-PdCTP labelled $\left(0.1-10 \times 10^{8} \mathrm{cpm} / \mu \mathrm{g}\right) \mathrm{cDNA}$ probes for human IGF-II (bases 1-854 of a cDNA encoding exons 7, 8, and part of 9 excised with Pst I) (Bell et al., 1984) and chicken $\beta$-actin ( $1.8 \mathrm{~kb}$ excised with $P$ st I) (Cleveland et al., 1980). Individual Nytran membranes were hybridized by stripping and reprobing, as described in the manufacturer's instructions (Schleicher and Schuell, Keene, NH). Relative OD for each hybridization was determined densitometrically by averaging several exposures in the linear range of the film. Experimental relative OD values were expressed as a percentage of the untreated (time zero) controls and then divided by the percentage of untreated control values similarly obtained for $\beta$-actin hybridizations.

\section{Radioimmunoassay}

RIA was performed essentially as previously described (Cullen et al., 1991). SH-SY5Y cells were plated $\left(3.7 \times 10^{6}\right.$ cells per T150 flask) and maintained in culture for 2 days. Cells were washed with DMEM and 20 $\mathrm{ml}$ fresh DMEM added. Medium was collected after 1,2, 3 , or 6 days, with a medium change on day 4 . Medium was centrifuged ( $2 \mathrm{~min}, 1,000 \mathrm{rpm}$ ) to remove any cellular debris and the protease inhibitors PMSF $(0.1 \mu \mathrm{g} / \mathrm{ml})$ and aprotinin $(2 \mu \mathrm{g} / \mathrm{ml})$ added to inhibit protein degradation. Medium was concentrated with Centriprep-3 concentrators (MW cut-off $=3,000$ Daltons, Amicon, Beverly, MA), and acetic acid added to a final concentration of $0.1 \mathrm{M}$ prior to storage at $-70^{\circ} \mathrm{C}$. As described (Cullen et al., 1991), IGF binding proteins were separated from the IGF via double extraction with Sep-Pak $\mathrm{C}_{18}$ columns (Millipore, Bedford, MA) (Osborne et al., 1989) and assayed before and after column separation by an activated charcoal binding protein assay (Powell et al., 1987). Double extraction removed over $90 \%$ of the binding proteins. Samples or IGF-II standards, ${ }^{125} \mathrm{I}$ IGF-II $(20,000-30,000 \mathrm{cpm}$, Amersham, Arlington Heights, IL) and $0.6 \mathrm{ng}$ of rat monoclonal antibody against IGF-II (Upstate Biotechnologies, Lake Placid, NY) were incubated in RIA buffer ( $1 \%$ BSA, $0.1 \mathrm{M}$ $\mathrm{NaH}_{2} \mathrm{PO}_{4}, \mathrm{pH} 7.4,0.02 \%$ sodium azide) overnight. Bound IGF-II-antibody complexes were precipitated by addition of $5 \%$ human $\gamma$-globulin and $25 \%$ polyethylene glycol, then removed and counted on a $\gamma$-counter (Tm Analytic 1290, Tampa, FL).

\section{RESULTS}

\section{Cell proliferation in serum-free media}

We measured the rate of SH-SY5Y cell proliferation in sparsely plated cells $\left(3 \times 10^{4}\right.$ cells $\left./ \mathrm{cm}^{2}\right)$ over 6 days in serum and serum-free media by counting the number of viable cells. SH-SY 5Y cells rapidly proliferated when cultured in serum, exhibiting a 14-fold increase in cell number after 6 days (Fig. 1). However, in serum-free media, sparsely plated cells exhibited no significant change in SH-SY5Y cell number over the entire 6-day treatment period (Fig. 1). Because cultured cells often exhibit density dependent growth, we asked whether densely plated SH-SY5Y cells could survive and proliferate in serum-free media. For these experiments, we plated cells at four different densities for 2 days in

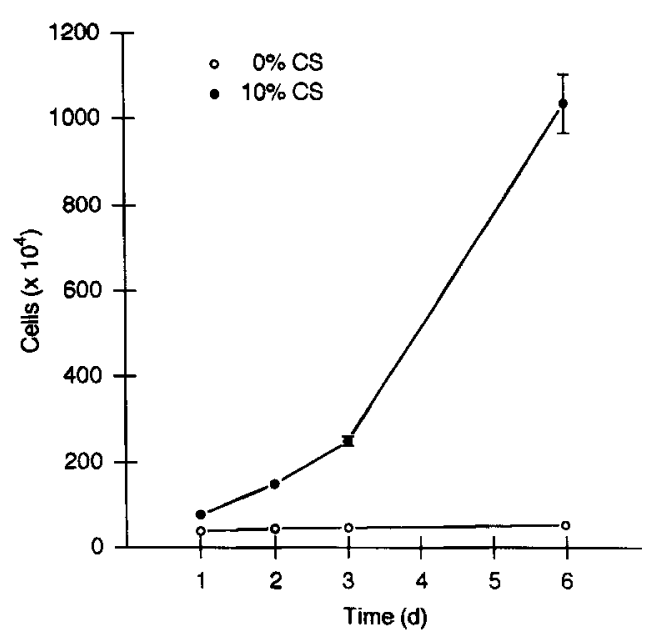

Fig. 1. Effects of serum and serum-free media on SH-SY5Y cell proliferation. Cells were plated in DMEM $+10 \% \mathrm{CS}$ and allowed to grow for 2 days, then rinsed with DMEM, and fresh DMEM (0) or DMEM + $10 \%$ CS $(\bullet$ ) was added. Viable cells were counted by trypan blue dye exclusion either immediately (untreated) or after $1,2,3$, or 6 days, with a media change on day 4 . Cell numbers, expressed as cells $\times 10^{4}$, are the means \pm SEM of triplicate wells from a representative experiment performed twice. Error bars were omitted where they were too small to be visible.

serum, then washed and treated cells with serum-free media. Cell number was determined either immediately (no media change) or after 1 or 3 days (Fig. 2a). At relatively low plating densities ( 3 and $6 \times 10^{4}$ cells/ $\mathrm{cm}^{2}$ ), there were no significant changes in cell number over the entire 3-day serum-deprivation period. However, at higher plating densities $\left(9-12 \times 10^{4} \mathrm{cells} / \mathrm{cm}^{2}\right)$, cell number increased significantly after 3 days in serum-free media. To eliminate the possibility that SHSY5Y cell growth in serum-free media was due to residual serum, cells were rinsed and plated directly in serum-free media and cell number was measured after 1-7 days by MTT assay (Hansen et al., 1989). SH-SY5Y cell plating efficiency was similar in serum-containing and serum-free media. We observed density dependent SH-SY5Y cell growth in these experiments also, as early as one day after cell plating (Fig. 2b). The rate of SH-SY5Y cell division in serum-free media increased with increasing cell plating density, similar to our observation for cells treated first with serum and then serum deprived (compare $\mathrm{a}$ and $\mathrm{b}$ in Fig. 2). When plated directly in serum-free media, SH-SY5Y cells $\left(9 \times 10^{4} \mathrm{cells} / \mathrm{cm}^{2}\right)$ exhibited a greater than twofold increase in cell number after 7 days (Fig. 2b). Cells plated more densely $\left(12-21 \times 10^{4}\right.$ cells $\left./ \mathrm{cm}^{2}\right)$ proliferated faster, exhibiting three- to sixfold increases in cell number after 5 days in serum-free media (Fig. 2b). OD readings were below the detectable range for cells plated at $3-6 \times 10^{4}$ cells $/ \mathrm{cm}^{2}$ and above the detectable range after 7 days for cells plated at 18 and $21 \mathrm{cells} / \mathrm{cm}^{2}$.

\section{SH-SY5Y cells produce IGF-II protein}

The density dependence of SH-SY5Y cell proliferation, combined with earlier observations that these cells express IGF-II mRNA and IGF receptors (Martin et al., 1992), suggested the presence of an IGF-II medi- 


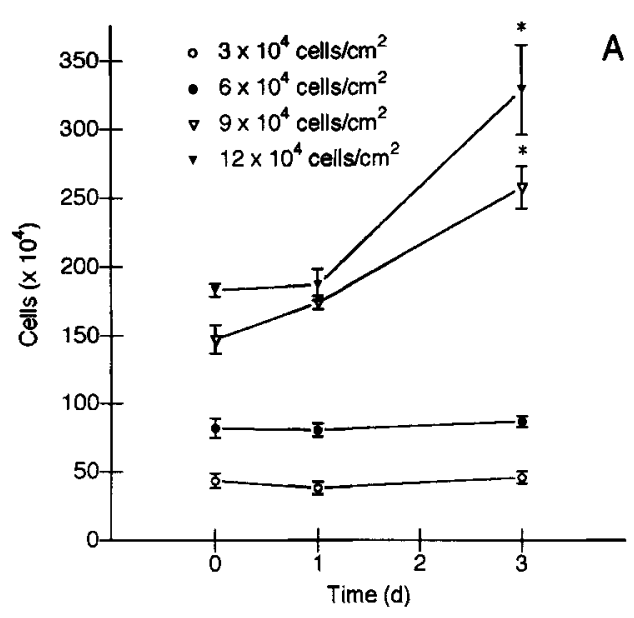

Fig. 2. Density dependent SH-SY5Y cell proliferation in serum-free media. Cells were plated in serum, then serum deprived (A) or plated directly in serum-free media (B). In A, cells were plated in DMEM $+10 \%$ CS $\left(6\right.$-well dishes at $3-12 \times 10^{4}$ cells $/ \mathrm{cm}^{2}$, as indicated in the legend) and allowed to grow for 2 days. Cells were then rinsed with DMEM, and fresh DMEM was added. Cell number was determined by trypan blue dye exclusion either immediately (no media change) or after 1 or 3 days. Cell numbers, expressed as cells $\times 10^{4}$, are means of triplicate wells \pm SEM. In B, cells were rinsed thor-

ated autocrine growth mechanism. To determine whether IGF-II protein is also produced by these cells, we performed an IGF-II-specific RIA on SH-SY5Y celltioned media. These experiments were performed in serum-free media and not in the presence of serum, because serum contains IGF-II (Enberg and Hall, 1984). SH-SY5Y cells also express several binding proteins that complex with IGF-II (Feldman et al., 1992). It was therefore necessary to remove these binding proteins prior to IGF-II RIA. Fractions of eluate after two consecutive binding protein extractions were collected, pooled, and assayed by RIA. Dilutions of the pooled fractions exhibited similar inhibition of ${ }^{125}$ I-IGF-II tracer binding to antibody as did human recombinant IGF-II (Fig. 3). The concentration of immunoreactive IGF-II present in SH-SY5Y cell serum-free conditioned media after 3 days was $1.31 \pm 0.11 \mathrm{nM}(9.68 \pm 0.84$ $\mathrm{ng} / \mathrm{ml}$ ).

\section{Regulation of IGF-II gene expression}

RIA of serum-free media conditioned by SH-SY5Y cells for $1,2,3$, or 6 days revealed a steady increase in the amount of immunoreactive IGF-II (Fig. 4). The concentration of immunoreactive IGF-II increased over twofold between 1 and 3 days, from $0.47 \pm 0.04 \mathrm{nM}$ $(3.48 \pm 0.30 \mathrm{ng} / \mathrm{ml})$ to $1.31 \pm 0.11 \mathrm{nM}(9.68 \pm 0.84 \mathrm{ng} /$ $\mathrm{ml}$ ) and did not change thereafter (Fig. 4). The concentration of immunoreactive IGF-II after 6 days was $1.30 \pm 0.16 \mathrm{nM}(9.62 \pm 1.18 \mathrm{ng} / \mathrm{ml})$, similar to the concentration present after 3 days. Because there was a complete media change on day 4 , the concentration of IGF-II present in SH-SY5Y cell conditioned media after 6 days represents the total cumulative amount produced by these cells in 2 days. This value may therefore underestimate the amount of IGF-II produced by $\mathrm{SH}$ SY5Y cells in 6 days. As described (Fig. 1), there was no

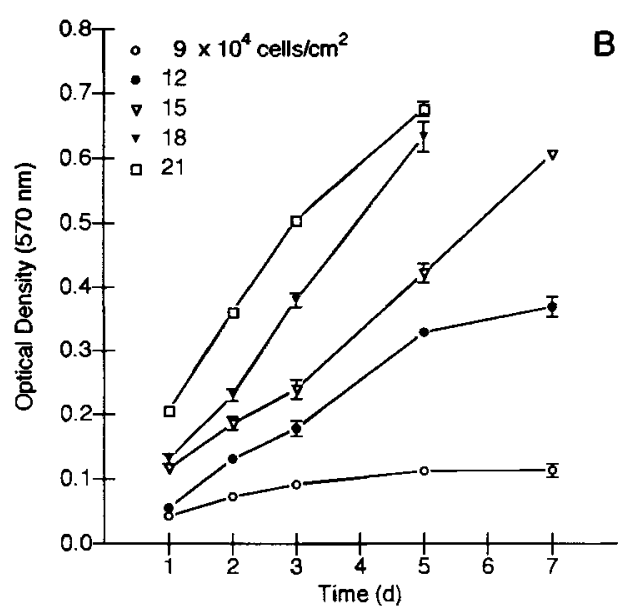

oughly in DMEM and plated in 96-wells $\left(9-21 \times 10^{4}\right.$ cells $/ \mathrm{cm}^{2}$, as indicated in the legend). Cell number was measured by MTT assay after $1,3,5$, or 7 days, with a media change on day 4 . Relative OD 1570 $\mathrm{nm}$ ) values are means of 8 wells $\pm \mathrm{SEM}$. Cell number was significantly higher on each day compared to day 1 values for all five densities tested (asterisks deleted for visual clarity). All data are from representative experiments performed twice. Error bars were omitted where they were too small to be visible. ${ }^{*} P<0.05$ compared to day zero values by unpaired, two-tailed $t$-test.

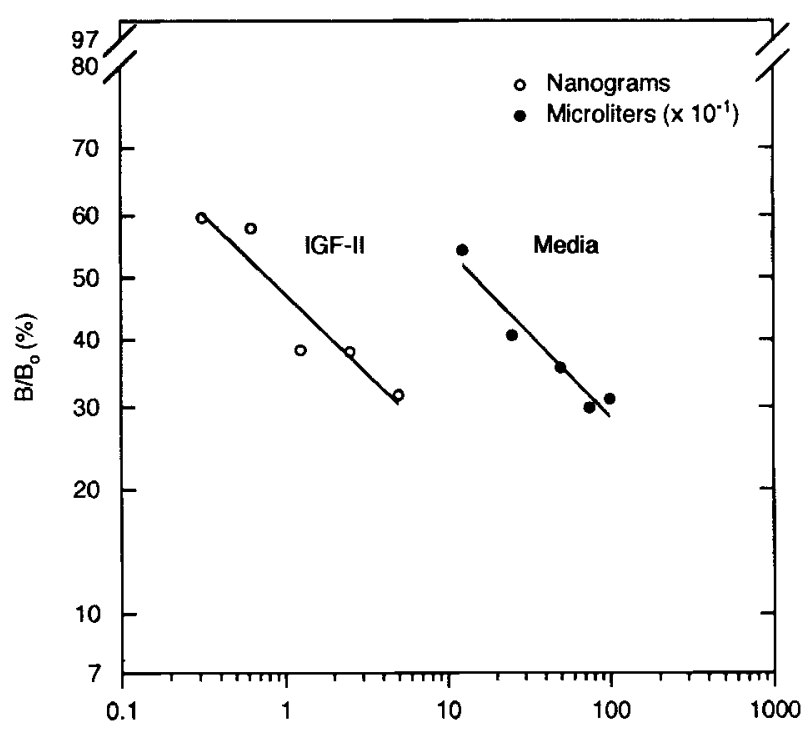

Fig. 3. IGF-II immunoreactive protein in SH-SY5Y cell conditioned media. Cells were plated at $2.5 \times 10^{4}$ cells $/ \mathrm{cm}^{2}$ in T150 flasks for 2 days in DMEM + 10\% CS, then rinsed in DMEM, and $20 \mathrm{ml}$ fresh DMEM added for an additional 3-day incubation. Medium was then collected and concentrated, binding proteins removed, and medium assayed for IGF-II levels. B/B $\mathrm{B}_{0}$ (\% of maximum) vs. ng of IGF-II (o) or $\mu l$ of media ( ) assayed is plotted on a logit-log scale. Maximum bind ing was $32 \%$ of input radioactivity. $\mathrm{K}_{\mathrm{d}}=2.2 \mathrm{nM}$.

change in SH-SY5Y cell number in serum-free media under these plating conditions.

Increased IGF-II was also detected at the mRNA level. SH-SY5Y cells express three IGF-II RNA transcripts, $1.8,4.8$, and $6.0 \mathrm{~kb}$ in length (Martin et al., 


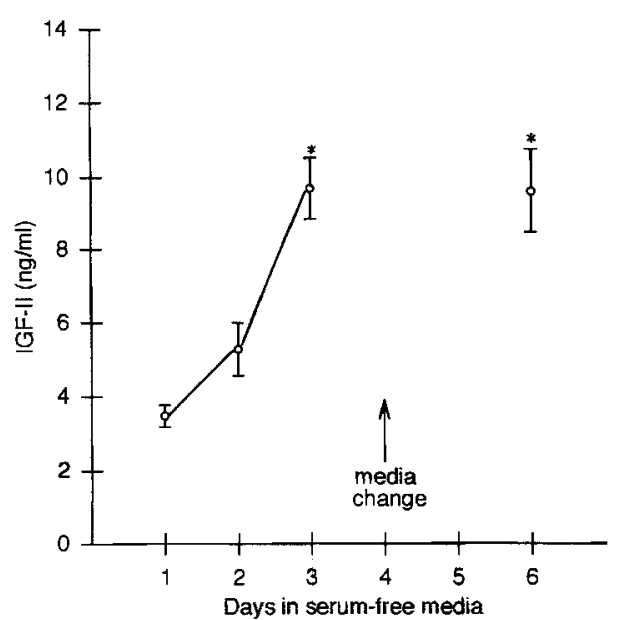

Fig. 4. RIA of IGF-II protein from SH-SY $5 Y$ cell conditioned media. Cells were plated at $2.5 \times 10^{4}$ cells $/ \mathrm{cm}^{2}$ in T150 flasks for 2 days in DMEM $+10 \%$ CS. Cells were then rinsed in DMEM and $20 \mathrm{ml}$ fresh DMEM added for a $1,2,3$, or 6 day incubation, with a media change on day 4. Media were collected and concentrated, binding proteins removed, and media assayed for IGF-II levels. Values in nM are the concentrations of IGF-II protein present in SH-SY5Y conditioned media. Data are the means of two experiments $\pm \mathrm{SEM}$. ${ }^{*} P<0.05 \mathrm{com}$ pared to day 1 untreated control values by unpaired, two-tailed $t$-test.

1992). By Northern analysis of total RNA from SHSY5Y cells, we detected these same three IGF-II mRNA transcripts, with a relative abundance of $6.0>$ $4.8>1.8 \mathrm{~kb}$ (Fig. 5). We therefore used $6.0 \mathrm{~kb}$ IGF-II mRNA as a representative measure for total IGF-II mRNA content. IGF-II mRNA was rapidly up-regulated with serum deprivation, by sixfold after 1 day and by 37 -fold after 6 days (Fig. 5a). Increased IGF-II mRNA with serum deprivation was observed under the same plating conditions as our observed increase in immunoreactive IGF-II (compare Figs. 4 and 5). We also detected a tenfold rise in $6.0 \mathrm{~kb}$ IGF-II mRNA content after 3 days in serum and a 26 -fold increase after 6 days (Fig. 5b). Thus, $6.0 \mathrm{~kb}$ IGF-II mRNA content increased more rapidly in serum-free media than in serum. We detected a $30 \%$ reduction in $\beta$-actin mRNA content after 1 day in serum-free media, which was otherwise unchanged during the entire 6-day serum deprivation period (Fig. 5c). $\beta$-actin mRNA content did not change significantly with time in serum.

\section{Effects of serum deprivation and IGF-II on DNA synthesis and the cell cycle}

Our finding that sparsely plated SH-SY5Y cells do not proliferate in serum-free media led us to speculate that serum deprivation may alter the rate of DNA synthesis or progression through the cell cycle. By ${ }^{3} \mathrm{H}-\mathrm{TdR}$ incorporation, we found that sparsely plated, serumdeprived cells synthesized DNA in a time-dependent fashion. ${ }^{3} \mathrm{H}$-TdR incorporation per cell decreased in $\mathrm{SH}$ SY $5 Y$ cells by fivefold after 24 hours of serum deprivation, then increased back to control levels between 24 and 48 hours (Fig. 6a). To better characterize the decrease in ${ }^{3} \mathrm{H}$-TdR incorporation observed after 24 hours of serum deprivation, we performed a more detailed time course analysis of ${ }^{3} \mathrm{H}-\mathrm{TdR}$ incorporation in serumfree media (Fig. 6b). There was no detectable change in cell number with serum deprivation, so data are presented as total ${ }^{3} \mathrm{H}$-TdR incorporation instead of on a per cell basis, as for Figure $6 \mathrm{a}$. We detected a similar decrease in ${ }^{3} \mathrm{H}$-TdR incorporation during the first 24 hours of serum deprivation, which steadily increased thereafter.

Previous studies have shown that brief ( $20 \mathrm{hr}$ ) exposures to IGF-II stimulate DNA synthesis in SH-SY5Y cells (Mattsson et al., 1986, 1990). To better characterize the response of SH-SY5Y cells to IGF-II, we measured ${ }^{3} \mathrm{H}-\mathrm{TdR}$ incorporation after $1-6$ days of IGF-II (1-10 nM) treatment. IGF-II stimulated ${ }^{3} \mathrm{H}-\mathrm{TdR}$ incorporation per cell in a dose- and time-dependent fashion (Fig. 6a). Optimal stimulation of ${ }^{3} \mathrm{H}-\mathrm{TdR}$ incorporation relative to serum-free media was achieved after a 48 -h incubation in $3 \mathrm{nM}$ IGF-II (Fig. 6a). ${ }^{3} \mathrm{H}-\mathrm{TdR}$ incorporation was also enhanced by $1 \mathrm{nM}$ IGF-II, a concentration of IGF-II similar to that produced by SH-SY5Y cells (Figs. 4, 6a). Treatment with serum or IGF-II for $72 \mathrm{~h}$ resulted in an apparent inhibition of ${ }^{3} \mathrm{H}$-TdR incorporation relative to the serum-free control (Fig. 6a). However, both IGF-II and serum increased cell number over time (Table 1), indicating that the rate of ${ }^{3} \mathrm{H}$-TdR incorporation may decrease with increasing cell density (compare Fig. 6a and Table 1).

To determine whether increased DNA synthesis with serum deprivation or IGF-II treatment could be associated with increases in the number of cells synthesizing DNA, we performed nuclear labelling experiments (Fig. 7a, b). S phase nuclei were labelled by incorporation of BrdU into DNA, which was then detected immunocytochemically with BrdU-specific antibodies. The number of BrdU-labelled nuclei was determined by microscopic image analysis and expressed as a percentage of the total number of nuclei. Cells were plated at a relatively low density $\left(5 \times 10^{3}\right.$ cells $\left./ \mathrm{cm}^{2}\right)$ for these experiments to facilitate visualization of labelled and unlabeled nuclei. In serum-free media, nuclear labelling index increased between 1 and 2 days (Fig. $7 \mathrm{~b}$ ), similar to our observed trend in ${ }^{3} \mathrm{H}-\mathrm{TdR}$ incorporation with serum deprivation (Fig. 6a). As early as 1 day following IGF-II (10 nM) treatment, BrdU nuclear labeling index was increased by two-fold relative to serum-free media (Fig. 7b). After 3- or 5-day incubations in IGF-II, nuclear labelling index was decreased relative to the serum-free controls (Fig. $7 \mathrm{~b}$ ).

Serum deprivation and IGF-II treatment could also regulate the SH-SY5Y cell cycle period. For these experiments, we assayed DNA content by flow cytometry over a 3-day incubation period in the presence or absence of IGF-II or serum. In serum-treated cells there was a relatively constant proportion of cells in each phase of the cell cycle, at all time points tested (Table 2 ). In contrast, cells treated with serum-free media exhibited varying percentages of cells in each phase of the cell cycle. After the first $24 \mathrm{~h}$ of serum deprivation, there was a greater than twofold decrease in the percentage of cells in $S$ phase relative to serum-treated cells, with a corresponding increase in the percentage of cells in $\mathrm{G}_{0} / \mathrm{G}_{1}$ (Table 2). After 3 days in serum-free media, the percentage of cells in S-phase was similar to 


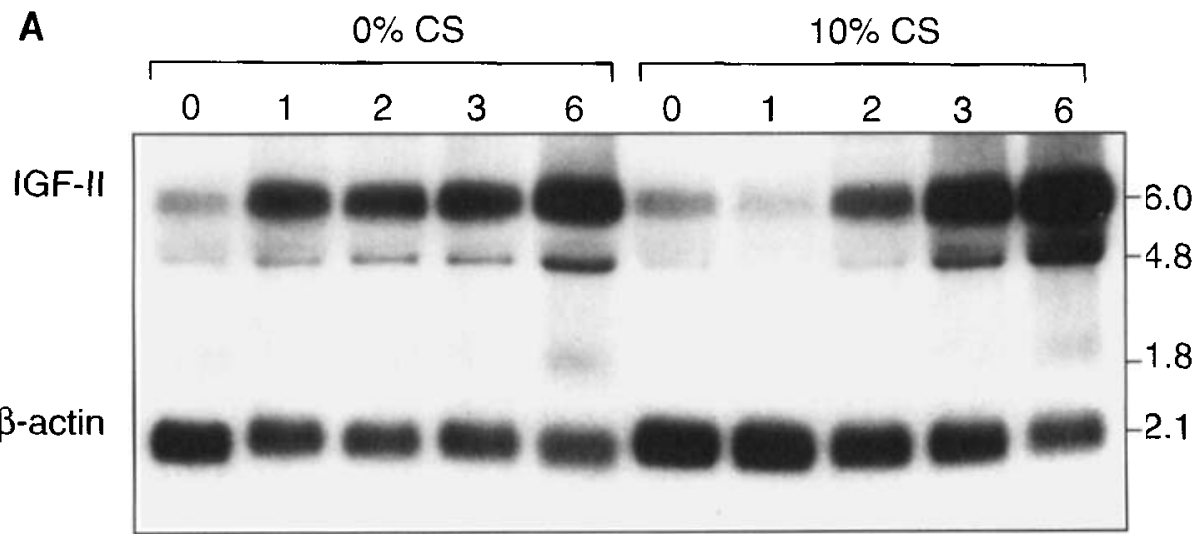

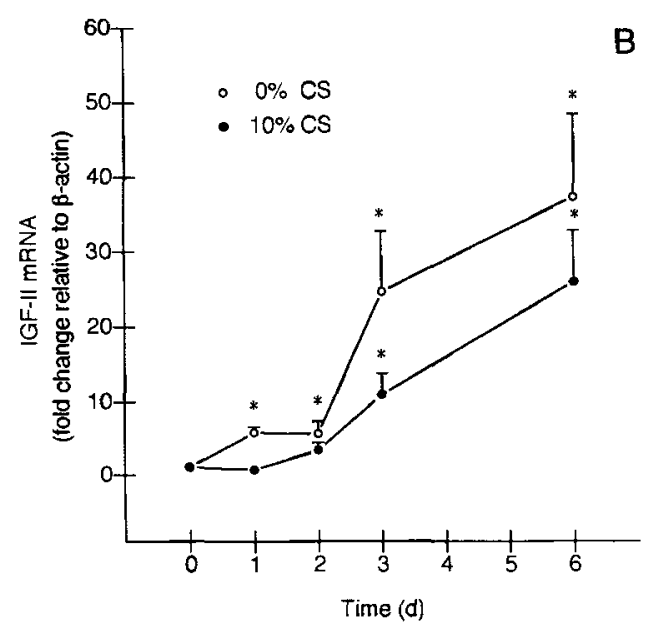

Fig. 5. Northern analysis of IGF-II mRNA. SH-SY5Y cells were plated at $2.5 \times 10^{4}$ cells $/ \mathrm{cm}^{2}$ for 2 days in DMEM $+10 \% \mathrm{CS}$, rinsed in DMEM, then treated with DMEM $\pm 10 \% \mathrm{CS}$. A. Autoradiograph from Northern blot of IGF-II and $\beta$-actin mRNA. RNA was isolated either immediately (untreated) or after 1,2,3, or 6 day incubation, with a media change on day 4 . Northern analysis was performed with ${ }^{32} \mathrm{P}$ labelled cDNA probes for IGF-II and $\beta$-actin, as indicated in Materials and Methods. Days are indicated above each lane; RNA transcript sizes in $\mathrm{kb}$ are listed at the right of each autoradiograph. Autoradiographs exposed $8 \mathrm{~h}$ (IGF-II) and $4 \mathrm{~d}$ ( $\beta$-actin). B and $\mathbf{C}$. Densitometric analysis of IGF-II (B) and $\beta$-actin (C) mRNA. Autoradiographs from

that of serum-treated cells, indicating that cells re-enter $\mathrm{S}$ phase sometime between 1 and 3 days after transfer to serum-free media. With serum deprivation, the percentage of cells in $\mathrm{S}$ followed a time course similar to ${ }^{3} \mathrm{H}$-TdR incorporation and BrdU nuclear labelling index (compare Figs. 6, 7 with Table 2). Treatment of SH-SY5Y cells with IGF-II (1-10 $\mathrm{nM}$ ) for $24 \mathrm{~h}$ had no significant effects on the percentage of cells in $\mathrm{S}$ phase relative to serum-free media (Table 2). The percentage of cells in $\mathrm{G}_{2} / \mathrm{M}$ was lower in serum-free media than in serum treated cells at all time points tested.

\section{Antibodies against IGF-II block proliferation}

To determine whether endogenously produced IGF-II could support SH-SY5Y cell growth and survival, we multiple exposures of the experiment shown in $\mathrm{A}$ and at least three additional experiments were quantitated using relative $O D$, as deseribed in Materials and Methods. Values in B are means \pm SEM of the ratio of $6.0 \mathrm{~kb}$ IGF-II mRNA relative OD to $\beta$-actin relative OD, expressed as a percentage of time zero untreated control. Values in $\mathrm{C}$ are means $\pm S E M$ of $\beta$-actin relative $O D$ expressed as a percentage of time zero untreated control. In $C$, the number the observations is indicated in parentheses above each time point. $* P<0.05$ compared to time zero untreated control values for $0 \% \operatorname{CS}(0)$ or $10 \%$ CS $(\bullet)$ by unpaired, two-tailed $t$ test.

performed proliferation assays using anti-IGF-II antibodies. In these experiments, SH-SY5Y cells were plated in serum-free media in the presence or absence of IGF-II and IGF-II antibodies, and cell number was measured by the MTT assay (Hansen et al., 1989). In serum-free media alone, SH-SY5Y cell number increased threefold after 5 days in serum-free media (Fig. 8a). Addition of IGF-II (1-10 nM) increased cell number above the serum-free media control at all time points tested, whereas in the presence of anti-IGF-II antibody, SH-SY5Y cell number did not change over the entire 7-day incubation period (Fig. 8a). Addition of increasing concentrations of IGF-II with the antiIGF-II antibody prevented the decrease in cell number observed with the antibody alone, whereas isotypic 


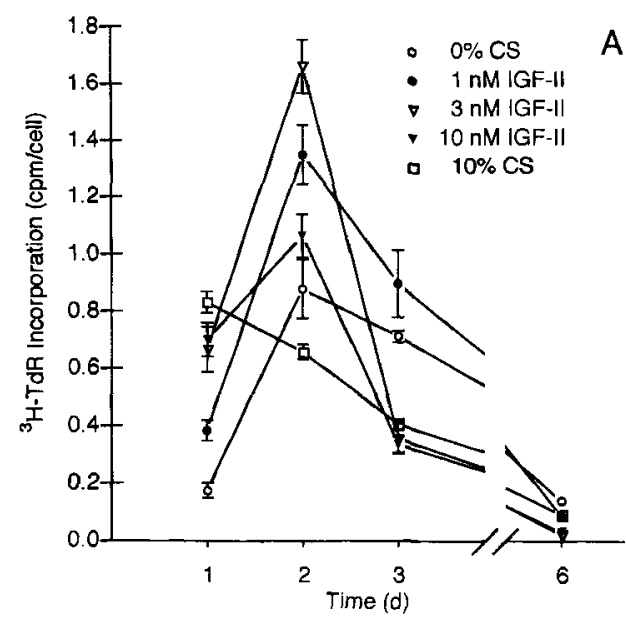

Fig. 6. Effects of IGF-II (A) and serum deprivation (A,B) on ${ }^{3} \mathrm{H}-\mathrm{TdR}$ incorporation. SH-SY5Y cells were plated at $3 \times 10^{4}$ cells $/ \mathrm{cm}^{2}$ in DMEM $+10 \%$ CS for 2 days, then rinsed in DMEM and treated with DMEM \pm IGF-II $(1,3$ or $10 \mathrm{nM})$ or $10 \% \mathrm{CS} .{ }^{3} \mathrm{H}$-TdR incorporation and viable cell number (determined by trypan blue dye exclusion) were measured in parallel wells either immediately (untreated) or after 1 ,

MOPC-21 antibody had no significant effect on cell number (Fig. 8 b).

\section{DISCUSSION \\ IGF-II is up-regulated in serum-free media}

In this study, we found that SH-SY5Y cells actively proliferate in serum-free media if plated at high densities. Density-dependent cell growth has been observed previously in other cell types, including keratinocytes (Shipley et al., 1989), and can indicate the presence of a concentration-dependent, endogenously produced growth-promoting activity (Cook et al., 1991). Using a RIA, we detected immunoreactive IGF-II protein in SHSY5Y cell conditioned media at a concentration (1.5 $\mathrm{nM}$ ) within the range of IGF-II concentrations shown to stimulate DNA synthesis. These results suggest that in the absence of serum, SH-SY5Y cells continuously synthesize and secrete IGF-II protein. The concentration of immunoreactive IGF-II present in SH-SY5Y cell media increased with time, to more than threefold after 3 days. This result is consistent with an earlier report in mouse muscle cell conditioned media showing increased IGF-II protein with low serum (Florini et al.,

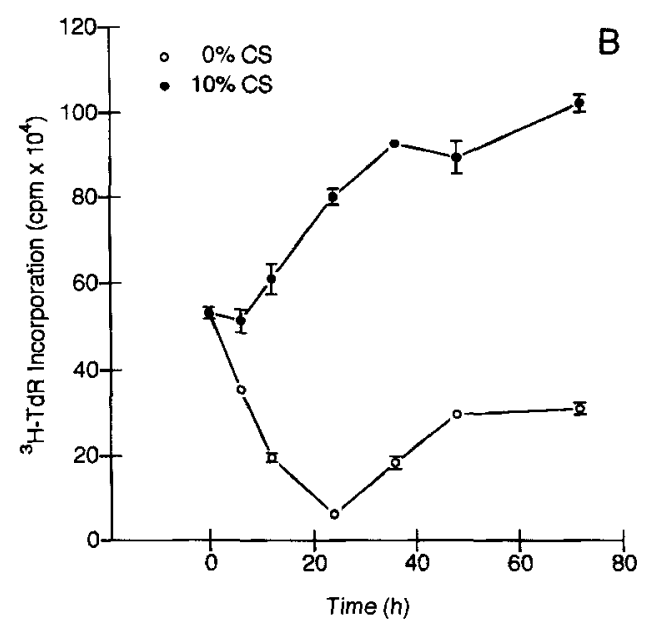

2,3 , or 6 days, with a media change at day 4 . Values in $\mathbf{A}$, expressed as cpm per cell are means of triplicate wells \pm SEM. Values in $\mathbf{B}$, expressed as $\mathrm{cpm} \times 10^{4}$, are means of triplicate wells $\pm \mathrm{SEM}$. All data are from representative experiments performed twice. In A, untreated control $=0.94 \pm 0.17 \mathrm{cpm} / \mathrm{cell}$. Error bars were omitted where they were too small to be visible.

1991). Similar increases in IGF-I during serum deprivation have been reported in human fibroblasts (Clemmons and Shaw, 1983) and lung cancer cells (Macaulay et al., 1990).

We also observed increased IGF-II mRNA within 1 day of serum deprivation. This increase in IGF-II mRNA was not associated with an increase in cell number but rather with a sharp decline in the rate of DNA synthesis. These observations suggest that IGF-II expression in low density cells is up-regulated at the mRNA level by mechanisms associated with growth arrest. We also observed a steady rise in IGF-II expression with time in serum-containing media under conditions where the rate of DNA synthesis also decreased. We speculate that endogenously produced factors in SH-SY5Y cell conditioned media stimulate IGF-II expression and that this effect is density dependent. One obvious candidate for such a feedback control mechanism of IGF-II expression is IGF-II itself. Our findings are consistent with studies in mouse muscle cells where increased IGF-II mRNA is detected within $16 \mathrm{~h}$ after transfer to low-serum media (Tollefsen et al., 1989; Florini et al., 1991). IGF-II up-regulation has also been

TABLE 1. Time course of serum deprivation and IGF-II effects on cell number ${ }^{1}$

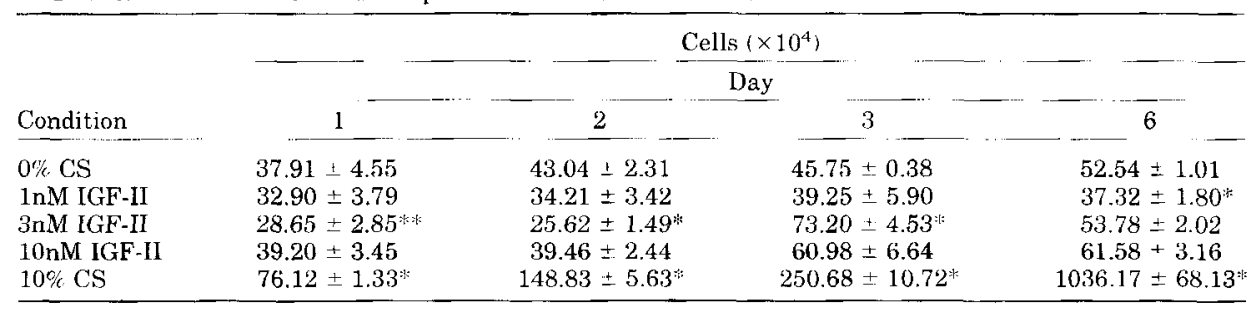

${ }^{1}$ Cell number as determined by trypan blue dye exclusion. Data expressed as cells $\times 10^{4}$ are means of triplicate wells from the same experiments shown in Figure 6 a.

${ }^{*} P<0.05$ compared to $0 \%$ CS control at each time point by unpaired, two-tailed $t$-test.

* $n-2$. 

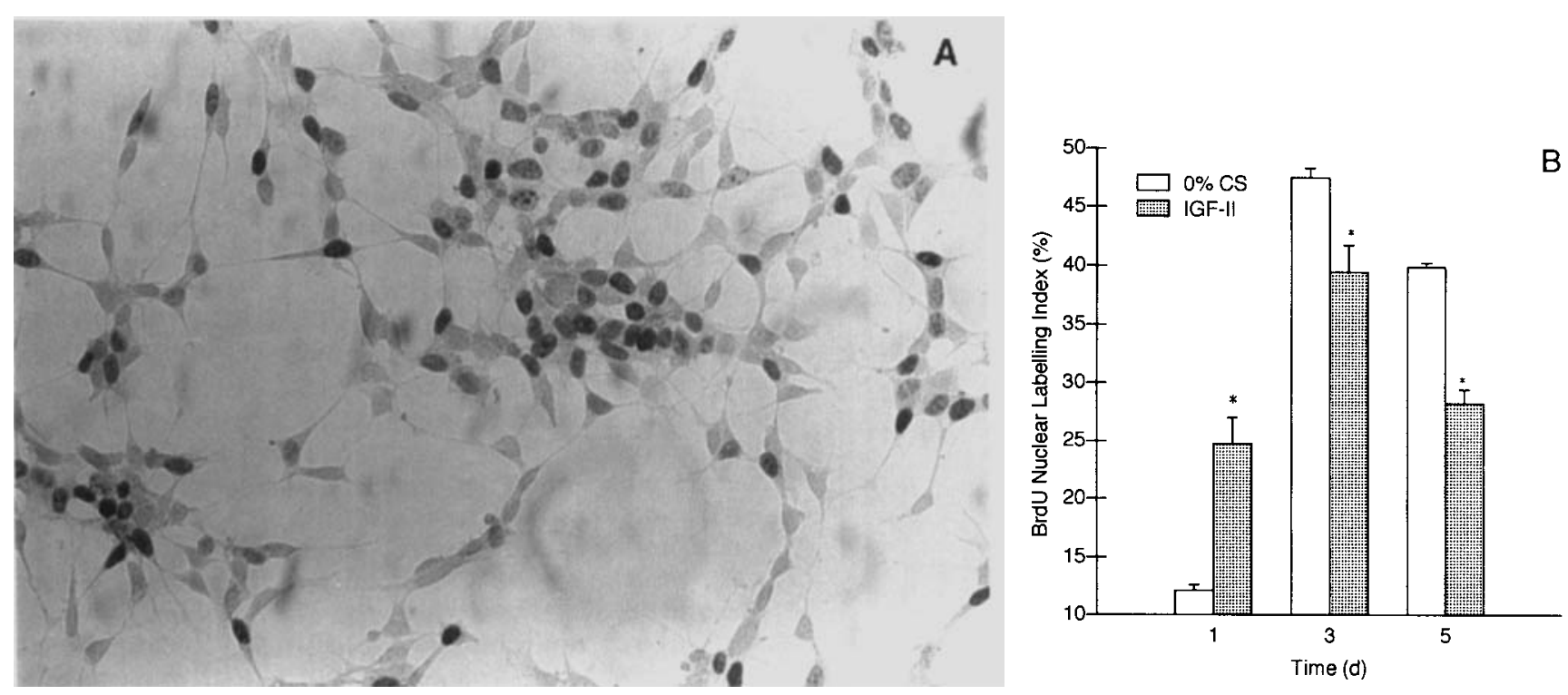

Fig. 7. Effects of serum deprivation and IGF-II on SH-SY5Y nuclear labelling index. Cells $\left(5 \times 10^{3}\right.$ cells $\left./ \mathrm{cm}^{2}\right)$ were plated onto glass coverslips and allowed to grow in DMEM $+10 \%$ CS for 2 days. Cells were then rinsed with DMEM and fresh DMEM \pm IGF-II (10 nM) added After 1, 3, or 5 days, with a media change on day 4 , cells were incubated with BrdU $(10 \mu \mathrm{M})$, then fixed and processed for BrdU immunocytochemistry as described in Materials and Methods. A. Brightfield photomicrograph of BrdU-stained SH-SY5Y cells. B. A minimum of 250 total cells were counted by computerized microscopic image analysis, and the number of BrdU-labelled nuclei expressed as a percentage of the total. Values are the means of triplicate coverslips \pm SEM from a representative experiment performed twice. ${ }^{*} P<0.05 \mathrm{com}-$ pared to 0\% CS by unpaired, two-tailed $t$-test.

TABLE 2. Effects of IGF-II and serum deprivation on SH-SY5Y cell cycle'

\begin{tabular}{|c|c|c|c|c|c|c|c|c|c|}
\hline \multirow[b]{3}{*}{ Condition } & \multicolumn{3}{|c|}{$\mathrm{G}_{0} / \mathrm{G}_{1}$} & \multicolumn{3}{|c|}{$\mathrm{S}(\%)$} & \multicolumn{3}{|c|}{$\mathrm{G}_{2} / \mathrm{M}(\%)$} \\
\hline & \multicolumn{3}{|c|}{ Day } & \multicolumn{3}{|c|}{ Day } & \multicolumn{3}{|c|}{ Day } \\
\hline & 0 & 1 & 3 & 0 & 1 & 3 & 0 & 1 & 3 \\
\hline $0 \% \mathrm{CS}$ & 47.2 & 78.3 & 66.1 & 46.2 & 8.2 & 29.4 & 6.5 & 13.5 & 4.6 \\
\hline $\ln M$ & 47.2 & 81.6 & 66.0 & 46.2 & 4.8 & 29.3 & 6.5 & 13.6 & 4.7 \\
\hline $3 \mathrm{nM}$ & 47.2 & 82.3 & 67.3 & 46.2 & 5.3 & 29.2 & 6.5 & 12.3 & 3.5 \\
\hline $10 \mathrm{nM}$ & 47.2 & 81.3 & 62.9 & 46.2 & 9.4 & 3.7 & 6.5 & 9.2 & 0 \\
\hline $10 \% \mathrm{CS}$ & 47.2 & 55.1 & 70.0 & 46.2 & 33.4 & 20.2 & 6.5 & 11.5 & 9.8 \\
\hline
\end{tabular}

${ }^{1}$ The percentage of cells in each phase of the cell cycle was determined by flow cylometry as described in Materials and Methods. Data are from a representative experiment performed twice.

detected after growth hormone treatment in hypophysectomized rat brain (Hynes et al., 1987) and in primary human adrenal cells after exposure to ACTH (Voutilainen and Miller, 1987). We do not know whether increased IGF-II mRNA content is due to an increase in the rate of DNA transcription into RNA and/or in mRNA stability. In serum, actinomycin D studies indicate the half-life of the $6.0 \mathrm{~kb}$ IGF-II mRNA transcript is about $10 \mathrm{~h}$ (Sussenbach et al., 1991). Whereas other studies have reported changes in relative expression levels of the 6.0 and $4.8 \mathrm{~kb}$ IGF-II mRNA transcripts with serum stimulation (Meinsma et al., 1991), we observed no differences in the relative abundance of the $6.0,4.8$, or $1.8 \mathrm{~kb}$ IGF-II transcripts in serum or serum-free media.

\section{Serum deprivation partially growth arrests SH-SY5Y cells}

Our observed increase in IGF-II mRNA after $24 \mathrm{~h}$ of serum deprivation was associated with sharp decreases in DNA synthesis and the percentage of cells in $\mathrm{S}$ phase. The percentage of cells in $G_{0} / G_{1}$ phases of the cell cycle significantly increased during the initial $24-h$ serum deprivation. These results indicate that serum deprivation of low density SH-SY5Y cells initially arrests the great majority $(80 \%)$ in $\mathrm{G}_{0} / \mathrm{G}_{1}$ phases of the cell cycle. Our data are consistent with an earlier report showing a similar but shorter ( $12 \mathrm{~h}$ ) lag phase in DNA synthesis for fibroblasts arrested in $\mathrm{G}_{0} / \mathrm{G}_{1}$ by serum deprivation (Pledger et al., 1977). After longer periods of serum deprivation, both DNA synthesis per cell and the percentage of cells in $\mathrm{S}$ phase returned to untreated control levels, suggesting a recovery mechanism that is able to overcome the initial serum deprivation shock on the cell cycle. We detected a small but significant fraction of cells in $\mathrm{G}_{2} / \mathrm{M}$ phases of the cell cycle with serum deprivation, indicating that some cells continue dividing in the absence of serum, even at low densities. The small percentage of cells actively dividing in serumfree media was not associated with an increase in the number of viable cells, based on results from trypan blue dye assays. 

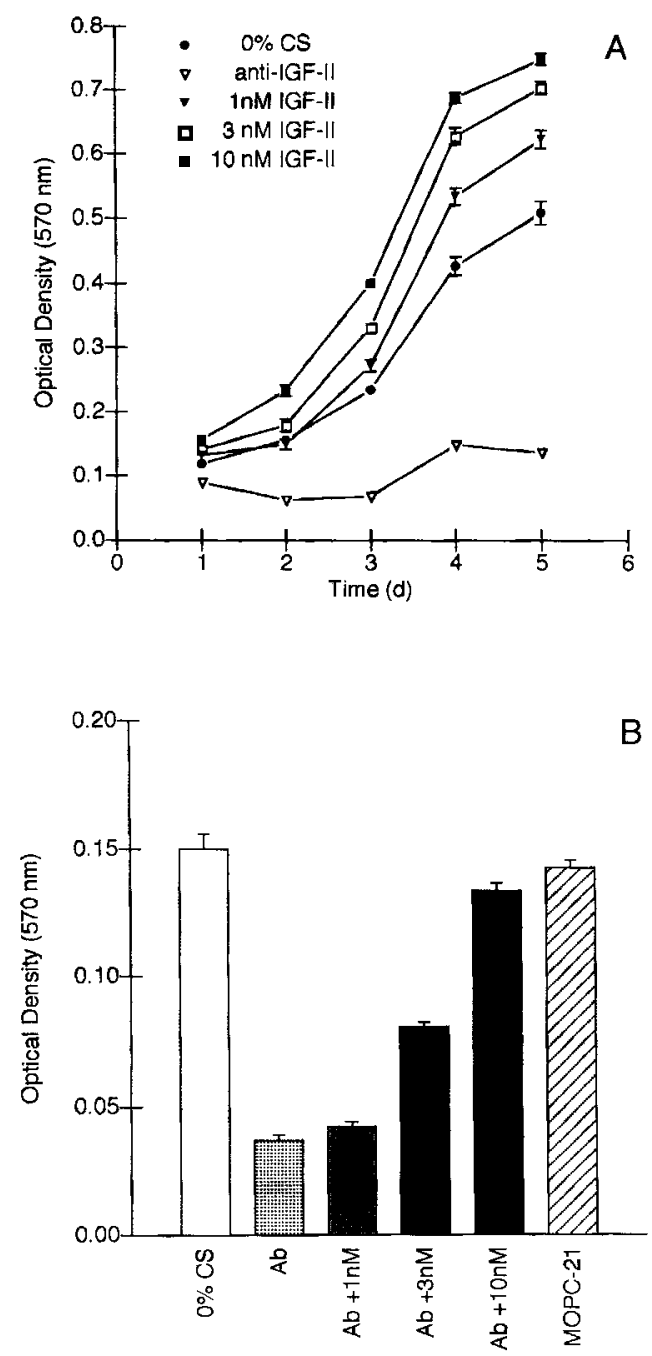

Fig. 8. Effects of IGF-II and anti-IGF-II antibody on SH-SY5Y cell proliferation. SH-SY5Y cells were washed in DMEM and plated in 96-wells at $9 \times 10^{4}$ cells/ $/ \mathrm{cm}^{2}$ in DMEM $\pm 1,3$ or $10 \mathrm{nM} \mathrm{lGF-II} \mathrm{and} \pm$ anti-IGF-II antibody $(1 \mu \mathrm{g} / \mathrm{ml})$ and \pm MOPC-21 antibody $(1 \mu \mathrm{g} / \mathrm{ml})$ Cell proliferation was measured at various time points using the MTT assay. Symbols in A: $(\bullet) 0 \% \mathrm{CS},(\nabla) 1 \mu \mathrm{g} / \mathrm{ml}$ anti-IGF-II antibody, $(\nabla)$ $1 \mathrm{nM}$ IGF-II, () $3 \mathrm{nM}$ IGF-II, (-) $10 \mathrm{nM}$ IGF-II. In $\mathbf{B}$, cells were incubated for 3 days in the conditions listed on the $\mathrm{X}$-axis $(\mathrm{Ab}=$ antiIGF-II antibody). In A and B, optical densities ( $570 \mathrm{~nm}$ ) are the mean of eight wells = SEM from representative experiments performed three times. Error bars were omitted where they were too small to be visible.

\section{IGF-II increases DNA synthesis and cell cycling time}

IGFs have been shown to stimulate DNA synthesis (Mattsson et al., 1986) and progression of cells through $\mathrm{G}_{0} / \mathrm{G}_{1}+\mathrm{S}$ phases of the cell cycle (Leof et al., 1982; DiCicco-Bloom and Black, 1988) and have therefore been termed "progression factors" (Leof et al., 1982). Using DNA synthesis assays and flow cytometry, we tested the effects of IGF-II on SH-SY5Y cell S phase activity and the distribution of cells in various phases of the cell cycle. We found that long exposures (2-6 days) to IGF-II inhibited ${ }^{3} \mathrm{H}-\mathrm{TdR}$ incorporation, whereas short ( $24 \mathrm{~h}$ ) exposures stimulated ${ }^{3} \mathrm{H}$-TdR incorporation. This observation is consistent with the 24-h stimulation by IGF-II reported by Mattsson et al. (1986). Increased ${ }^{3} \mathrm{H}$-TdR incorporation could indicate an increase in the number of nuclei actively synthesizing DNA or the rate of DNA synthesis. To assay for the first of these two possibilities, we performed nuclear labelling index experiments with BrdU in sparsely plated SH-SY5Y cells incubated in serum-free media with or without IGF-II. We found that IGF-II (10 nM) increased the nuclear labeling index by twofold after 1 day relative to serum-free media, suggesting exogenously added IGF-II promotes entry of SH-SY5Y cells into $\mathrm{S}$ phase. This finding corroborates data from Lundy and colleagues (1991) who reported increased BrdU nuclear labelling index after a 24-h treatment of embryonic chicken calvarial cells with IGF-II $(0.30-30$ nM). Similarly, DiCicco-Bloom and Black (1988) have shown that IGF-II increases the nuclear labelling index in fetal rat neuroblasts. Collectively, these observations support the proposed role of IGF-II in promoting neuroblast entry into S phase. Interestingly, IGF-II inhibited nuclear labelling index after 3 and 5 days, similar to its long-term effects on ${ }^{3} \mathrm{H}$-TdR incorporation. The reason for IGF-II inhibition of ${ }^{3} \mathrm{H}-\mathrm{TdR}$ incorporation and BrdU labelling index after long exposures to IGF-II is not known. The half-life of IGF-II protein is about $4 \mathrm{~h}$ (Zapf et al., 1986), and it is possible that IGF-II degradation product inhibit DNA synthesis. Alternatively, IGF binding proteins, also produced by SHSY5Y cells (Feldman et al., 1992), are known to modulate IGF expression and function (Clemmons, 1991) and may serve a similar role here. Support for this notion comes from our observation that serum, which also contains IGF binding proteins, likewise inhibited ${ }^{3} \mathrm{H}-\mathrm{TdR}$ incorporation after long exposures.

We performed flow cytometry experiments to test for effects of IGF-II on the distribution of cells in the cell cycle and overall cell cycle time. Addition of 1-10 nM IGF-II for 1 or 3 days had no significant effect on the percentage of cells in each phase of the cell cycle, relative to serum-free media. Because BrdU experiments were performed at a lower density than the ${ }^{3} \mathrm{H}-\mathrm{TdR}$ and flow cytometry assays, it is possible that the potential effects of IGF-II on entry into S-phase are density-dependent. Alternatively, IGF-II induced increases in cell number and DNA synthesis could occur without affecting the distribution of cells in the cell cycle. This effect may result from an IGF-II induced increase in the overall cell cycling time. Chen and colleagues have observed a similar phenomenon with IGF-I, where they found that IGF-I increases the exit rate of fibroblasts from $\mathrm{G}_{0} / \mathrm{G}_{1}$ to $\mathrm{S}$, but does not affect the cycling fraction (Chen and Rabinovitch, 1989).

\section{Evidence for autocrine IGF-II mediated proliferation}

Expression of IGF-II at the RNA and protein levels and regulation of the SH-SY5Y cell cycle suggested that these cells may use endogenously produced IGF-II as a growth-promoting agent. To test this hypothesis, we determined the effects of anti-IGF-II blocking antibodies on SH-SY5Y growth and survival in serum-free 
media. We found that addition of anti-IGF-II to cells at the time of plating in serum-free media significantly decreased SH-SY5Y cell proliferation and that addition of exogenous IGF-II with the antibody prevented this inhibition. These results strongly suggest that IGF-II acts as an autocrine growth factor in SH-SY5Y cells. This finding corroborates an earlier report by El-Badry and colleagues, who showed that other human neuroblastomas use IGF-II as an autocrine mitogen (ElBadry et al., 1989). In comparison to the neuroblastoma cell lines and tissues used in their studies, SH-SY5Y cells exhibit relatively weak autocrine IGF-II growth. For example, the SK-N-AS line can survive for many months in serum-free media, whereas SH-SY5Y cells begin to detach from their substrate after about 1 week (El-Badry et al., 1989). One explanation for the different rates of neuroblastoma cell proliferation may be the presence of factors in the defined media or the poly-D lysine and fibronectin substrata used in their study. Autocrine IGF-II growth mechanisms have been detected in other systems as well, including early mammalian embryogenesis (Rappolee et al., 1992), human placental development (Ohlsson et al., 1989), and mouse muscle cell differentiation (Florini et al., 1991), as well as in other transformed cells such as rhabdomyosarcoma, breast cancer, and stomach carcinoma (Osborne et al., 1989; El-Badry et al., 1990; Thompson et al., 1990). Our results in neuroblastoma cells further support growing evidence that IGF-II serves an autocrine or paracrine function in developing and transformed cells (Daughaday, 1990).

In summary, the results of our experiments demonstrate that SH-SY5Y cells synthesize, secrete, and respond to IGF-II as part of an autocrine growth mechanism. Increased IGF-II expression was associated with changes in DNA synthesis and the SH-SY5Y cell cycle and may be a necessary part of autocrine cell survival that is especially exaggerated in serum-free media. Future experiments will help determine whether IGF-II binding to IGF receptors and/or binding proteins is also regulated by serum withdrawal. Certainly, our finding that expression of IGF-II is enhanced in serum-free media will provide a basis for the identification of clinically applicable agents for controlling neuroblastoma cell growth.

\section{ACKNOWLEDGMENTS}

We thank Ann Randolph and Mihir Meghani for assistance with experiments. Drs. Graeme Bell and Don Cleveland provided cDNA probes. We thank Dr. Douglas Greene for helpful discussions, and Dr. Anders Sima for assistance with image analysis. DMM was supported by NIH training grant NS 07222-09 and ELF by NIH grant NS01380.

\section{LITERATURE CITED}

Bell, G.I., Merryweather, J.P., Sanchez-Pescador, R., Stempien, M.M. Priestly, L., Scott J., and Rall, L.B. (1984) Sequence of a cDNA clone encoding human preproinsulin-like growth factor II. Nature 310:775-777.

Biedler, J.L., Roffler-Tarlov, S., Schachner, M., and Freedman, L.S. (1978) Multiple neurotransmitter synthesis by human neuroblastoma cell lines and clones. Cancer Res., 38:3751-3757.

Bothwell, M. (1982) Insulin and somatomedin MSA promote nerve growth factor-independent neurite formation by cultured chick dorsal root ganglionic sensory neurons. J. Neurosci. Res., 8:225-231.

Chen, Y., and Rabinovitch, P.S. (1989) Platelet-derived growth factor, epidermal growth factor, and insulin-like growth factor I regulate specific cell-cycle parameters of human diploid fibroblasts in serumfree culture. J. Cell. Physiol., 140:59-67.

Chomczynski, P., and Sacchi, N. (1987) Single-step method of RNA isolation by acid guanidinium thiocyanate-phenol-chloroform extraction. Anal. Biochem., 162:156-159.

Clemmons, D.R. (1991) Insulin-like growth factor binding proteins: Roles in regulating IGF physiology. J. Dev. Physiol., 15:105-110.

Clemmons, D.R., and Shaw, D.S. (1983) Variables controlling somatomedin production by cultured human fibroblasts. J. Cell. Physiol., 115:137-142.

Cleveland, D.W., Lopata, M.A., MacDonald, R.J., Cowan, N.J., Rutter, W.J., and Kirschner, M.W. (1980) Number and evolutionary conservation of $\alpha$ - and $\beta$-tubulin and cytoplasmic $\beta$ - and $\gamma$-actin genes using specific cloned cDNA probes. Cell, 20:95-105.

Cook, P.W., Pittelkow, M.R., and Shipley, G.D. (1991) Growth factorindependent proliferation of normal human neonatal keratinocytes: production of autocrine- and paracrine-acting mitogenic factors. $J$ Cell. Physiol., 146:277-289.

Cullen, K.J., Smith, H.S., Hill, S., Rosen, N., and Lippman, M.E (1991) Growth factor messenger RNA expression by human breast fibroblasts from benign and malignant lesions. Cancer Res., $51: 4978-4985$

Daughaday, W.H. (1990) Editorial: The possible autocrine/paracrine and endocrine roles of insulin-like growth factors of human tumors. Endocrinology, 127(1):1-4.

DiCicco-Bloom, E., and Black, I.B. (1988) Insulin growth factors regulate the mitotic cycle in cultured rat sympathetic neuroblasts. Proc. Natl. Acad. Sci. USA, 85:4066 4070.

El-Badry, O.M., Romanus, J.A., Helman, L.J., Cooper, M.J., Rechler, M.M., and Israel, M.A. (1989) Autonomous growth of a human neuroblastoma cell line is mediated by insulin-like growth factor II. J. Clin. Invest., 84:829-839.

El-Badry, O.M., Minniti, C.P., Kohn, E.C., Houghton, P.J., Daughaday, W.J., and Helman, L.J. (1990) Insulin-like growth factor II acts as an autocrine growth and motility factor in human rhabdomyosarcoma tumors. Cell Growth Differ., 1:325-331.

Enberg, G., and Hall, K. (1984) Immunoreactive IGF-II in serum of healthy subjects and patients with growth hormone disturbances and uraemia. Acta Endocrinol., 107:165-170.

Feldman, E.L., and Randolph, A.E. (1991) Mannose 6-phosphate potentiates insulin-like growth factor II effects in cultured human neuroblastoma cells. Brain Res., 562:111-116.

Feldman, E.L., Randolph, A., Yee, D., and Martin, D.M. (1992) Regulation of insulin-like growth factor binding protein gene expression in cultured neurons. Endocrine Society Abstracts, 74:1166:343 (Abstract).

Florini, J.R., Magri, K.A., Ewton, D.Z., James, P.L., Grindstaff, K., and Rotwein, P.S. (1991) "Spontaneous" differentiation of skeletal myoblasts is dependent upon autocrine secretion of insulin-like growth factor-II. J. Biol. Chem., 266:15917-15923.

Hansen, M.B., Nielsen, S.E., and Berg, K. (1989) Re-examination and further development of a precise and rapid dye method for measuring cell growth/cell kill. J. Immunol. Methods, 119:203-210.

Hepler, J.E., and Lund, P.K. (1990) Molecular biology of the insulinlike growth factors. Relevance to nervous system function. Mol. Neurobiol., 4:93-127.

Hynes, M.A., Van Wyk, J.J., Brooks, P.J., D’Erocle, A.J., Jansen, M., and Lund, P.K. (1987) Growth hormone dependence of somatomedin-C/insulin-like growth factor-I and insulin-like growth factor-II messenger ribonucleic acids. Mol. Endocrinol., 1:233-242.

Leof, E.B., Wharton, W., and Van Wyk, J.J. (1982) Epidermal growth factor (EGF) and somatomedin C regulate $G 1$ progression in competent BALB/c-3T3 cells. Exp. Cell Res., 141:107-115

Lundy, M.W., Hendrix, T., Wergedal, J.E., and Baylink, D.J. (1991) Growth factor-induced proliferation of osteoblasts measured by bromodeoxyuridine immunocytochemistry. Growth Factors, 4:257-264.

Macaulay, V.M., Everard, M.J., Teale, J.D., Trott, P.A., Van Wyk, J.J., Smith, I.E., and Millar, J.L. (1990) Autocrine function for insulin-like growth factor I in human small cell lung cancer cell lines and fresh tumor cells. Cancer Res., 50:2511-2517.

Martin, D.M., Yee, D., Carlson, R.O., and Feldman, E.L. (1992) Gene expression of the insulin-like growth factors and their receptors in human neuroblastoma cells. Mol. Brain Res., 15:241-246.

Mattsson, M.E.K., Enberg, G., Ruusala, A., Hall, K, and Păhlman, S. (1986) Mitogenic response of human SH-SY5Y neuroblastoma cells 
to insulin-like growth factor I and II is dependent on the stage of differentiation. J. Cell Biol., 102:1949-1954.

Mattsson, M.E.K., Hammerling, U., Mohall, E., Hall, K., and Påhlman, S. (1990) Mitogenically uncoupled insulin and IGF-I receptors of differentiated human neuroblastoma cells are functional and mediate ligand-induced signals. Growth Factors, 2:251-265.

McKelvie, P.A., Rosen, K.M., Kinney, H.C., and Villa-Komaroff, L. (1992) Insulin-like growth factor II expression in the developing human brain. J. Neuropathol. Exp. Neurol., 51:464-471.

Meinsma, D., Holthuizen, P.E., Van den Brande, J.L., and Sussenbach, J.S. (1991) Specific endonucleolytic cleavage of IGF-II mRNAs. Biochem. Biophys. Res. Commun., 179:1509-1516.

Morgan, D.O., Jarnagin, K., and Roth, R.A. (1986) Purification and characterization of the receptor for insulin-like growth factor I. Biochemistry, 25:5560-5564.

Morgan, D.O., Edman, J.C., Standring, D.N., Fried, V.A., Smith, M.C. Roth, R.A., and Rutter, W.J. (1987) Insulin-like growth factor II receptor as a multifunctional binding protein. Nature, 329:301-307.

Ohlsson, R., Holmgren, L., Giaser, A., Szpecht, A., and Pfeifer-Ohlsson, S. (1989) Insulin-like growth factor 2 and short-range stimulatory loops in control of human placental growth. EMBO J., 8:19931999.

Osborne, C.K., Coronado, E.B., Kitten, L.J., Arteaga, C.I., Fuqua S.A.W., Ramasharma, K., Marshall, M., and Li, C.H. (1989) Insulinlike growth factor-II (IGF-II): A potential autocrine/paracrine growth factor for human breast cancer acting via the IGF-I receptor. Mol. Endocrinol., 3:1701-1709.

Påhlman, S., Mamaeva, S., Meyerson, G., Mattsson, M.E.K., Bjelfman, C., Örtoft, E., and Hammerling, U. (1990) Human neuroblastoma cells in culture: a model for neuronal cell differentiation and function. Acta Physiol. Scand., Suppl., 592:25-37.

Pledger, W.J., Stiles, C.D., Antoniades, H.N., and Scher, C.D. (1977) Induction of DNA synthesis in BALB/c 3T3 cells by serum components: reevaluation of the commitment process. Proc. Natl. Acad. Sci., USA, 74:4481-4485.

Powell, D.R., Lee, P.D.K., Shively, J.E., Eckenhausen, M., and Hintz, R.L. (1987) Method for purification of an insulin-like growth factorbinding protein produced by human HEP G2 hepatoma cells. J. Chromatogr., 420:163-170.

Rappolee, D.A., Sturm, K.S., Behrendtsen, O., Schultz, G.A., Pedersen, R.A., and Werb, Z. (1992) Insulin-like growth factor II acts through an endogenous growth pathway regulated by imprinting in early mouse embryos. Genes and Development, 6:939-952.

Recio-Pinto, E., and Ishii, D.N. (1988) Insulin and insulinlike growth factor receptors regulating neurite formation in cultured human neuroblastoma cells. J. Neurosci. Res., 19:312-320.

Recio-Pinto, E., Rechler, M.M., and Ishii, D.N. (1986) Effects of insulin, insulin-like growth factor-II and nerve growth factor on neurite formation and survival in cultured sympathetic and sensory neurons. J. Neurosci., 6:1211-1219.

Roth, R.A. (1988) Structure of the receptor for insulin-like growth factor II: the puzzle amplified. Science, 239:1269-1271.

Rotwein, P. (1991) Structure, evolution, expression and regulation of insulin-like growth factors I and II. Growth Factors, 5:3-18

Sara, V.R., and Hall, K. (1990) Insulin-like growth factors and their binding proteins. Physiol. Rev., 70(3):591-614.

Shipley, G.D., Keeble, W.W., Hendrickson, J.E., Coffey, R.J., Jr., and Pittelkow, M.R. (1989) Growth of normal human keratinocytes and fibroblasts in serum-free medium is stimulated by acidic and basic fibroblast growth factor. J. Cell. Physiol., 138:511-518.

Sussenbach, J.S., Steenbergh, P.H., Jansen, E., Meinsma, D., van Dijk, M.A., Holthuizen, P., de Moor, C.H., Jansen, M., and Van den Brande, J.L. (1991) Structure and post-transcriptional regulation of expression of the human IGF-I and -II genes. In: Modern concepts of Insulin-like Growth Factors, Vol. 1. E.M. Spencer, ed. Elsevier, New York, pp. 639-654.

Thompson, M.A., Cox, A.J., Whitehead, R.H., and Jonas, H.A. (1990) Autocrine regulation of human tumor cell proliferation by insulinlike growth factor II: an in-vitro model. Endocrinology, 126(6):3033-3042.

Tollefsen, S.E., Sadow, J.L., and Rotwein, P. (1989) Coordinate expression of insulin-like growth factor II and its receptor during muscle differentiation. Proc. Natl. Acad. Sci., USA, 86:1543-1547.

Voutilainen, R. and Miller, W.L. (1987) Coordinate tropic hormone regulation of mRNAs for insulin-like growth factor II and the cholesterol side-chain-cleavage enzyme, P450ssc, in human steroidogenic tissues. Proc. Natl. Acad. Sci., USA, 84:1590-1594.

Zapf, J,, Hauri, C., Waldvogel, M., and Froesch, E.R. (1986) Acute metabolic effects and half-lives of intravenously administered in sulinlike growth factors I and II in normal and hypophysectomized rats. J. Clin. Invest., 77:1768-1775. 